\title{
Effect of $17 \beta$-estradiol on milk production, hormone secretion, and mammary gland gene expression in dairy cows
}

\author{
J. J. Tong, ${ }^{*} \dagger$ I. M. Thompson, $†$ X. Zhao, $\ddagger$ and P. Lacasse ${ }^{1}$ \\ *Department of Clinical Veterinary Medicine, College of Veterinary Medicine, Northeast Agricultural University, Harbin, Heilongjiang Province, \\ P. R. China 150030 \\ †Sherbrooke Research and Development Centre, Agriculture and Agri-Food Canada, Sherbrooke, Quebec, Canada J1M 0C8 \\ fDepartment of Animal Science, McGill University, Sainte-Anne-de-Bellevue, Quebec, Canada H9X 3V9
}

\begin{abstract}
Estradiol inhibits milk production in dairy cows. The present study evaluated the effect of $17 \beta$-estradiol (E2) injections on prolactin (PRL) secretion and the mammary gland response to this hormone. Eight midlactation cows were used in a crossover design. During each experimental period, the cows were injected daily with either E2 $(2.5 \mathrm{mg})$ or soy oil $(2.5 \mathrm{~mL}$; control) for $7 \mathrm{~d}$. For each period, blood and milk samples were collected from $\mathrm{d}-4$ to 14 (relative to the first injection) to measure PRL, insulin-like growth factor-1, and cortisol concentrations. In addition, blood samples were collected during morning milking on $\mathrm{d}-4,2$, and 7 to determine the milking-induced PRL release. Mammary gland biopsies were collected on the last day of injections. Milk fat samples were collected from d 1 to 7 and on $\mathrm{d}$ 14. The mRNA levels of genes encoding proteins related to mammary activity ( $\alpha$-lactalbumin, $\beta$-casein, and acetyl-coenzyme A carboxylase), apoptosis (Bax, $B c l$, and caspase-3), PRL receptors (PRLR; long and short forms), signal transducer and activator of transcription 5 (STAT5A and STAT5B), and suppressors of cytokine signaling (SOCS2 and SOCS3) were evaluated by real-time reverse transcription PCR using RNA extracted from milk fat and mammary biopsies. Milk production was decreased moderately (about 9\%) by E2 injections during the treatment period. Estradiol injections increased basal PRL levels in serum and milk but did not affect milking-induced PRL release. Estradiol injections increased the plasma concentration of insulin-like growth factor-1 but did not affect cortisol concentration during the treatment period. In mammary tissue, the expression of $B c l 2$ was downregulated, whereas that of $S T A T 5 A$ and $B$ and the Bax:Bcl2 mRNA ratio was higher during E2 injections. The total STAT5 protein content in mammary tissue was elevated by E2
\end{abstract}

Received June 19, 2017.

Accepted November 2, 2017.

${ }^{1}$ Corresponding author: Pierre.Lacasse@agr.gc.ca injections. We found no significant difference observed for the other genes in mammary tissue or milk fat. The present data do not support the contention that E2 injections inhibit milk production by interfering with PRL signaling, but enhanced basal PRL concentration and STAT5 gene expression in mammary tissue.

Key words: estrogen, prolactin, lactation persistency

\section{INTRODUCTION}

In dairy cows, gestation is associated with a faster decline in milk production. During gestation, the secretion of steroids, estrogens, and progesterone increases (McCormack and Greenwald, 1974), and ovariectomy was shown to improve lactation persistency in nonpregnant dairy cows (Yart et al., 2012). Milk production was found to be reduced in women using oral contraceptives containing both estrogen and progestin, but not affected in women taking a progestin-only contraceptive (Tankeyoon et al., 1984). Accordingly, several studies have shown that exogenous $17 \beta$-estradiol (E2) decreases milk production in dairy cows (Bachman et al., 1988; Athie et al., 1996; Delbecchi et al., 2005), supporting the idea that E2 plays a pivotal role in the reduction of lactation persistency during gestation. However, the mechanism by which E2 modulates milk production is still unknown.

The most important role for the hormone prolactin (PRL) in mammals, as its name implies, is the control of lactation. In several mammals, suppression of PRL with bromocriptine strongly inhibits lactation (Taylor and Peaker, 1975; Flint and Gardner, 1994). Although the involvement of PRL in the control of ruminant lactation has been controversial, recent studies have indicated that PRL is also galactopoietic in dairy ruminants (Lacasse et al., 2016). Indeed, the inhibition of PRL release by a dopamine agonist reduces milk production in both cows (Lacasse et al., 2011; Ollier et al., 2013) and goats (Knight, 1993), and this effect is attenuated by PRL injection (Lollivier et al., 2015). Increasing the PRL concentration by administering a 
dopamine antagonist (domperidone) was found to increase milk production (Lacasse and Ollier, 2015). In addition, more apoptosis was found in the mammary glands of cows when PRL secretion was inhibited (Boutinaud et al., 2012), suggesting that PRL is a survival factor for mammary cells. Therefore, it is likely that PRL is an important factor for lactation persistency.

Some factors modulating milk production also affect PRL secretion. Long-day photoperiod increases PRL concentration and milk production (Peters et al., 1981; Bilodeau et al., 1989), whereas the administration of melatonin, a neurotransmitter produced during the night, and the restriction of feed decreases PRL and milk production (Auldist et al., 2007; Ollier et al., 2014). For its part, milking frequency affects lactation persistency, the expression of the PRL receptor (PRLR), and the milk response to PRL inhibition (Bernier-Dodier et al., 2011; Lacasse et al., 2011). Therefore, it is possible that some factors modulating milk production do so by affecting PRL secretion or the responsiveness of the mammary gland to this hormone.

No direct evidence has shown that E2 affects PRL signaling in bovines; however, E2 was found to inhibit the lactogenic effect of PRL in primate mammary tissue (Kleinberg et al., 1983). The intracellular signaling of both PRL and growth hormone (GH) involves the Janus kinase $(\mathbf{J A K}) /$ signal transducer and activator of transcription (STAT) pathway and is negatively regulated by suppressors of cytokine signaling (SOCS; Teglund et al., 1998; Krebs and Hilton, 2000). Estrogen has been shown to inhibit GH signaling by suppressing GH-induced JAK2 phosphorylation, an effect mediated by SOCS-2 in HEK293 cells (Leung et al., 2003). Therefore, the objective of our study was to determine whether the inhibition of milk synthesis by E2 in dairy cows is mediated by modulations of PRL secretion or mammary gland responsiveness to PRL or both.

\section{MATERIALS AND METHODS}

\section{Animals and Experimental Design}

The experimental protocol was conducted in compliance with the rules and guidelines of the Canadian Council on Animal Care (1993). Eight mid-lactation Holstein cows $(2.6 \pm 1.1$ parity and $118 \pm 19$ DIM $)$ were used in a crossover design. The cows received daily (at $1030 \mathrm{~h}$ ) s.c. injections of either E2 (2.5 mg; CDMV, Saint-Hyacinthe, QC, Canada) or soy oil (2.5 $\mathrm{mL}$; control, CTL) during the 7-d treatment period. A resting period of 3 wk separated the 2 treatment periods. The cows had free access to water and were housed in a tiestall barn. Lactating cows were milked twice daily (0800 and $2000 \mathrm{~h}$ ) throughout the experi- ment and data were recorded at each milking. The cows were fed a TMR at $0830 \mathrm{~h}$ containing (on a DM basis) $34.4 \%$ grass silage, $22.8 \%$ corn silage, $24.1 \%$ corn grain, $9.0 \%$ soybean meal, $3.6 \%$ beet pulp, $2.6 \%$ chopped dry hay, $1.8 \%$ nonmineral supplement, and $1.6 \%$ mineral supplement. The TMR provided (on a DM basis) $17.6 \%$ CP, 20.6\% ADF, 30.2\% ADF, $1.0 \%$ Ca, $0.4 \%$ P, $1.5 \%$ $\mathrm{K}$, and $1.56 \mathrm{Mcal} / \mathrm{kg}$ of $\mathrm{NE}_{\mathrm{L}}$. Feed intake was recorded daily from $\mathrm{d}-4$ (before the start of the treatments) to 14. One cow became ill during the second period and her data were removed from the data set.

Blood was collected (at $0730 \mathrm{~h}$ ) from the coccygeal vessels into uncoated and EDTA-coated Vacutainer tubes (Becton, Dickinson and Co., Rutherford, NJ) from $\mathrm{d}-4$ to 14 . All blood tubes without additives were left for approximately $2 \mathrm{~h}$ at room temperature to allow clotting before they were centrifuged $(1,900 \times$ $\left.g, 4^{\circ} \mathrm{C}, 15 \mathrm{~min}\right)$. Then, the serum was stored at $-20^{\circ} \mathrm{C}$ until determination of PRL and cortisol concentrations. All blood tubes containing EDTA were placed on ice immediately after collection and centrifuged at 1,900 $\times$ $g$ and $4^{\circ} \mathrm{C}$ for $15 \mathrm{~min}$. The plasma was stored at $-80^{\circ} \mathrm{C}$ until IGF-1 analysis. All analyses were performed on individual samples.

Before the experiment, a Silastic catheter (i.d. 1.02 mm, o.d. $2.16 \mathrm{~mm}$; Dow Corning Corp., Midland, MI) was inserted into the jugular vein of each cow. On $d$ $-4,2$, and 7 , blood samples were collected at -20 , $-10,0,3,5,7,10,15,20,25,30,40$, and $60 \mathrm{~min}$ relative to the start of morning milking to measure milking-induced cortisol and PRL releases. To apply a stimulus that would not be affected by factors such as the amount of milk harvested at milking, the procedure was repeated $6 \mathrm{~h}$ after morning milking on $\mathrm{d} 7$, but the milking stimulus was replaced by manual stimulation of the mammary gland. This was done by rubbing the udder and teats vigorously with the hands for 5 min. Blood samples were left for approximately $2 \mathrm{~h}$ at room temperature to allow clotting before they were centrifuged $\left(1,900 \times \mathrm{g}, 4^{\circ} \mathrm{C}, 15 \mathrm{~min}\right)$. The serum was then stored at $-20^{\circ} \mathrm{C}$ until determination of PRL and cortisol concentrations.

\section{Mammary Biopsies}

Mammary biopsies were obtained from 1 rear quarter on the last day (d 7) of the treatment period. Biopsies were collected 4 to $6 \mathrm{~h}$ after morning milking with the procedure previously described by de Lima et al. (2016). After collection, the mammary tissue was rinsed in sterile saline solution to remove all traces of blood and then cut into small pieces. The mammary tissue samples were immediately frozen in liquid nitrogen and then stored at $-80^{\circ} \mathrm{C}$ for further analyses of both RNA 
and protein. Biopsies were harvested from the same site with alternation between the right and left rear glands between periods.

\section{Milk Composition}

Milk samples were collected daily at morning milking from $\mathrm{d}-4$ to 11 and 14. Lactose, protein, and fat concentrations of milk was determined by mid-infrared reflectance spectrometry (MilkoScan FT 6000, Foss, Hillerød, Denmark) by a commercial laboratory (Valacta Inc., Sainte-Anne-de-Bellevue, QC, Canada). Aliquots of milk samples were defatted by centrifugation $\left(1,900 \times g, 4^{\circ} \mathrm{C}, 15 \mathrm{~min}\right)$ and then kept at $-20^{\circ} \mathrm{C}$ for further analyses of BSA and PRL. The concentration of BSA in milk was measured as an indicator of mammary tight junction permeability as previously described by Bernier-Dodier et al. (2011).

\section{Real-Time Reverse Transcription PCR}

To increase the number of time points, gene expression was evaluated on RNA extracted from both mammary tissue and milk fat (Cánovas et al., 2014). On d 1 to 7 , milk samples were manually collected $2 \mathrm{~h}$ after morning milking from each individual quarter in sterile $50-\mathrm{mL}$ tubes and kept on ice. Milk $(10 \mathrm{~mL})$ from each quarter was mixed in a new tube and centrifuged $(2,000$ $\left.\times g, 4^{\circ} \mathrm{C}, 10 \mathrm{~min}\right)$. The milk fat was added to TRIzol LS Reagent (Life Technologies, Grand Island, NY) to obtain a concentration of $0.5 \mathrm{~g}$ of fat $/ \mathrm{mL}$. The samples were stored at $-80^{\circ} \mathrm{C}$ until extraction. Before extraction, the samples were transferred into $2.0-\mathrm{mL}$ tubes and then centrifuged at $12,000 \times g$ and $4^{\circ} \mathrm{C}$ for $10 \mathrm{~min}$. The middle phase (between fat and pellet) was used for milk fat RNA extraction; RNA was extracted from mammary tissue (50-75 $\mathrm{mg}$ in $1 \mathrm{~mL}$ of TRIzol) and milk fat using TRIzol Reagent and TRIzol LS Reagent, respectively, with a PureLink RNA Mini Kit (Invitrogen, Carlsbad, CA) according to the manufacturer's instructions (TRIzol LS: https://assets.thermofisher .com/TFS-Assets/LSG/manuals/trizol_ls_reagent .pdf; TRIzol and PureLink RNA Mini Kit: https:// assets.thermofisher.com/TFS-Assets/LSG/manuals / purelink_rna_mini_kit_man.pdf). After extraction, RNA amounts were quantified by using a NanoDrop 1000 spectrophotometer (Wilmington, DE), and RNA integrity was assessed with an Agilent 2100 Bioanalyzer system (Agilent Technologies, Waldbronn, Germany) using an Agilent RNA 6000 Nano kit (Agilent Technologies) according to the manufacturer's instructions (https://www.agilent.com/cs/library/usermanuals/ Public/G2938-90034_RNA6000Nano_KG.pdf). Aver- age RNA integrity number for mammary gland RNA was 8.1 and was lower (3.03) than expected for milk fat. All samples were incubated with DNase I (New England Biolabs Inc., Ipswich, MA) at $37^{\circ} \mathrm{C}$ for 30 min to remove genomic DNA and were subsequently heat-denatured at $75^{\circ} \mathrm{C}$ for $15 \mathrm{~min}$. Total RNA $(1,000$ and $750 \mathrm{ng} /$ reaction for mammary tissue and milk fat, respectively) was reverse-transcribed to complementary DNA using High-Capacity cDNA Reverse Transcription Kits (Applied Biosystems Inc., Foster City, CA) following the manufacturer's instruction. Quantitative PCR was performed with PowerUp SYBR Green Master Mix (Applied Biosystems Inc.) through an initial activation-denaturation step $\left(50^{\circ} \mathrm{C}\right.$ for $2 \mathrm{~min} ; 95^{\circ} \mathrm{C}$ for $2 \mathrm{~min}$ ) and then 40 cycles of a 2-step amplification protocol $\left(95^{\circ} \mathrm{C}\right.$ for $3 \mathrm{~s}$ and $60^{\circ} \mathrm{C}$ for $\left.30 \mathrm{~s}\right)$ using a StepOnePlus Real-Time PCR System (Applied Biosystems Inc.). The primers used were either designed using the Ensembl gene browser (Yates et al., 2016) following the primer design of Brosseau et al. (2010; http://test.lgfus .ca/cgi-bin/designs/index.pl) or described in previous studies (Bernier-Dodier et al., 2011; Thompson et al., 2011; Dudemaine et al., 2014) and were synthesized by Integrated DNA Technologies (Coralville, IA; Table 1). The real-time PCR reactions contained a mixture of 3.0 $\mu \mathrm{L}$ of the $1 / 30$ diluted $\mathrm{cDNA}$ product for each specific primer in a final reaction volume of $10 \mu \mathrm{L}$. Triplicate reactions were performed for each sample and were run in parallel with a relative standard curve. Each standard curve for quantification of transcripts was prepared using an aliquot of each undiluted cDNA sample (mammary gland cDNA or milk fat cDNA separately; Applied Biosystems, 1997). This pool was diluted 1/7.5 first and serially diluted by a 2 -fold factor until a final dilution of $1 / 480$. An arbitrary starting value of 1,000 was attributed to $1 / 7.5$ dilution. For each experimental sample, the amount of reference and target gene was determined from the corresponding standard curve for which PCR efficiency was also determined; PCR efficiency for all genes was in the acceptable range of 90 to $110 \%$.

The genes ACTB, GAPDH, UXT, and RPS24 were evaluated as potential reference genes. The NormFinder program (Andersen et al., 2004) was used to assess the variability of candidate reference genes. The genes with the most stable expression were GAPDH and $U X T$ for the mammary gland samples and $A C T B$ and $U X T$ for the milk fat samples, and those genes were therefore used as the reference genes in our study. The PCR efficiency of reference genes $A C T B, G A P D H$, and UXT were $107.23,103.83$, and $99.037 \%$, respectively. Relative quantity ratios were calculated by dividing the relative quantity of target gene by geometric mean of relative quantity of selected reference genes. 
Table 1. Primers used during real-time PCR

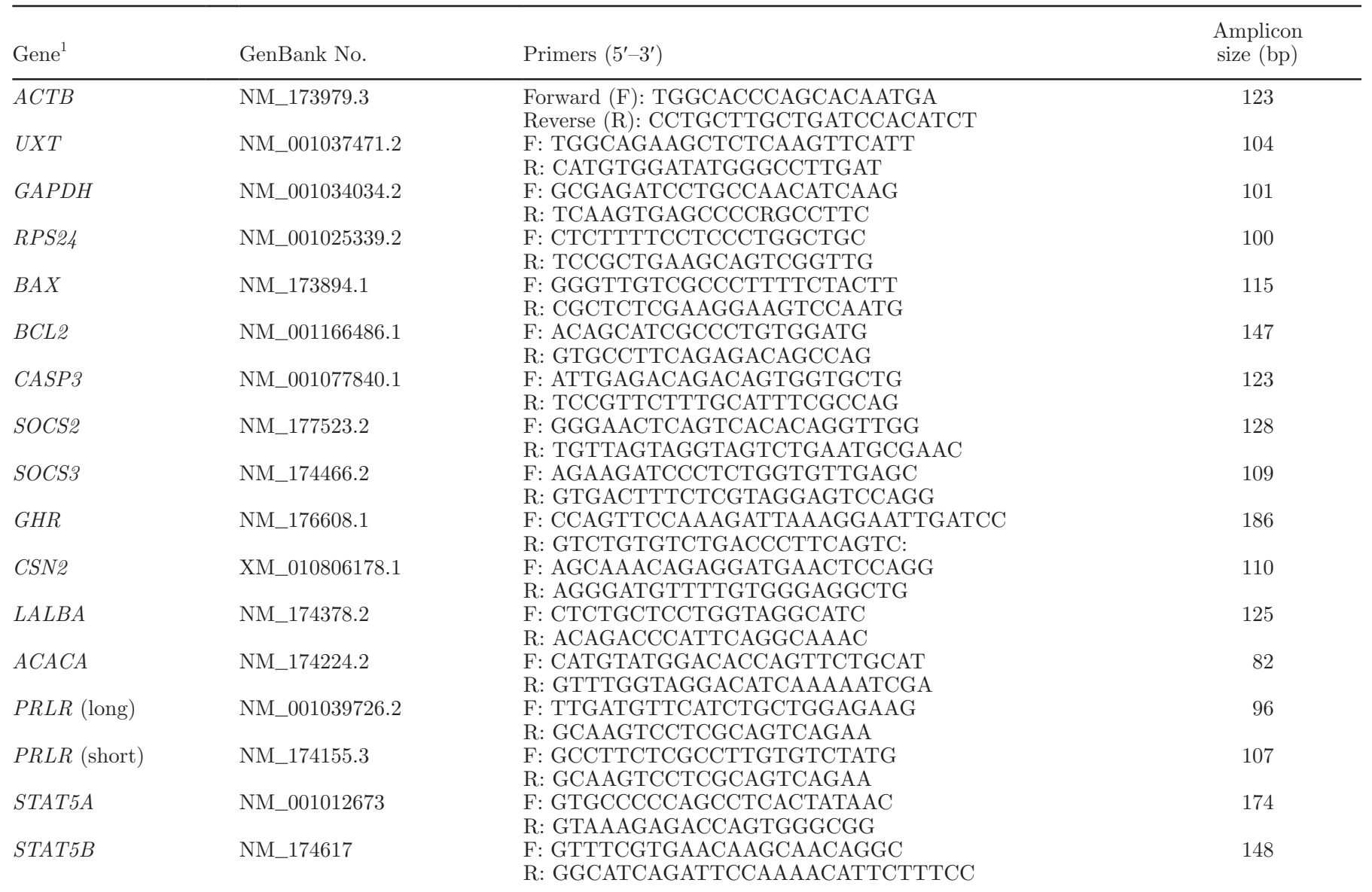

${ }^{1} A C T B=\beta$-actin, $U X T=$ ubiquitously expressed transcript $R P S 24=$ ribosomal protein S24; BAX = BCL2-associated X protein; $B C L 2=$ B-cell CLL/lymphoma 2; CASP3 = caspase-3; SOCS2, SOCS3 = suppressors of cytokine signaling 2 and 3; GHR = growth hormone receptor; $C S N 2=\beta$-casein; $L A L B A=\alpha$-lactalbumin; $A C A C A=$ acetyl-coenzyme A (CoA) carboxylase $\alpha ; P R L R$ (long) $=$ prolactin receptor, long isoform; PRLR (short) = prolactin receptor, short isoform; STAT5A = signal transducer and activator of transcription $5 \mathrm{~A} ; S T A T 5 B=$ signal transducer and activator of transcription $5 \mathrm{~B}$.

\section{Hormone Analysis}

The concentration of PRL in the serum and skim milk was measured by RIA, as previously described by Bernier-Dodier et al. (2011). Bovine PRL, rabbit antiserum specific for bovine PRL, and goat anti-rabbit gamma globulin were purchased from the National Hormone and Peptide Program (Harbor-UCLA Medical Center, Torrance, CA). The intra- and interassay coefficients of variation were 2.87 and $4.46 \%$, respectively.

The plasma concentration of E2 was measured using the Ultra-Sensitive Estradiol RIA Kit from Beckman Coulter (Mississauga, ON, Canada). The competitive RIA was carried out in accordance with the manufacturer's instructions, but with 2 modifications to the protocol: the E2 antiserum incubation time was increased to $75 \mathrm{~min}$ and a centrifugation speed of 1,900 $\times g$ was used. The intra- and interassay coefficients of variation were 3.59 and $10.55 \%$, respectively.
The serum concentration of cortisol and the plasma concentration of IGF-1 were determined by a commercial ELISA kit from R\&D Systems Inc. (Minneapolis, MN) according to the manufacturer's instructions (cortisol: https://www.rndsystems.com/products/cortisol -parameter-assay-kit_kge008\#assay-procedure; IGF-1: https://www.rndsystems.com/products/human-igf-i -quantikine-elisa-kit_dg100\#assay-procedure), which were slightly modified to increase the sample volume, leading to a dilution factor of 50 for IGF-1 analysis. The intra- and interassay coefficients of variation were, respectively, 6.65 and $6.30 \%$ for cortisol and 8.89 and $11.81 \%$ for IGF-1.

\section{Western Blot}

Snap-frozen mammary gland tissue was homogenized with a Kimble Chase glass tissue grinder (Kimble Chase Life Science and Research Products, Vineland, 
NJ) using the Mem-PER Plus Membrane Protein Extraction Kit (Thermo Fisher Scientific, Waltham, MA) with some modifications to the protocol. We used a ratio of tissue to permeabilization buffer of $120 \mathrm{mg}$ to $1 \mathrm{~mL}$ (soluble proteins), and then $0.5 \mathrm{~mL}$ of solubilization buffer was added to resuspend the resulting pellet (membrane proteins). Halt Protease and Phosphatase Inhibitor Cocktail $100 \times$ (Thermo Fisher Scientific) were added to both buffers before extraction $(10 \mu \mathrm{L} /$ $\mathrm{mL}$ of buffer). The resulting supernatants containing membrane proteins were assayed to determine protein concentrations against BSA standards using a Pierce BCA Protein Assay Kit (Thermo Fisher Scientific).

Samples $(15 \mu \mathrm{g})$ were heated at $70^{\circ} \mathrm{C}$ for $10 \mathrm{~min}$ in Lane Marker Reducing Sample Buffer (Thermo Fisher Scientific), to which extra dithiothreitol was added to a final concentration of $45 \mathrm{~m} M$. Denatured proteins were resolved under reducing conditions using a 7.5\% SDS-PAGE gel and then transferred to polyvinylidene fluoride membranes with a pore size of $0.20 \mu \mathrm{m}$ (Immun-Blot PVDF Membrane; Bio-Rad Laboratories, Saint-Laurent, QC, Canada). Total protein staining (Eaton et al., 2013; Gilda and Gomes, 2013) was used for loading control and normalization using the Swift Membrane Stain kit (G-Biosciences; VWR, Mississauga, ON, Canada). The membranes were blocked with $5 \%$ nonfat dried milk in Tris-buffered saline containing $0.1 \%$ (vol/vol) Tween 20 at room temperature for 1 $\mathrm{h}$. Bovine PRLR were detected using a mouse monoclonal IgG anti-PRLR antibody 1A2B1 (raised against the extracellular domain of hPRLR; Thermo Fisher Scientific) incubated at $4^{\circ} \mathrm{C}$ overnight and a horse antimouse IgG $\left(\mathrm{H}^{+} \mathrm{L}\right)$ HRP-linked antibody (New England Biolabs, Whitby, ON, Canada) incubated at room temperature for $1 \mathrm{~h}$. Both the first and second antibodies were diluted in 5\% nonfat dried milk in Tris-buffered saline Tween 20 at dilutions of $1 \mu \mathrm{g} / \mathrm{mL}$ and $34 \mathrm{ng} /$ $\mathrm{mL}$, respectively. Immunoreactivity was detected using enhanced chemiluminescence (Amersham ECL Prime Western Blotting Reagent, VWR). Molecular size determinations were made using Precision Plus Protein All Blue Standards (Bio-Rad Laboratories). Membrane pictures were digitized using a Fusion FX imaging system, and the protein band intensities of bovine PRLRlong (LF) and -short (SF) isoforms and total proteins were quantified by densitometry using Bio1D software (Vilber Lourmat, Marne-La-Vallée, France) and corrected for amounts of total proteins loaded.

\section{Determination of STAT Protein and Activation Levels}

Snap-frozen mammary gland tissue was homogenized with a Kimble Chase glass tissue grinder to extract cytoplasmic, membrane, and nuclear proteins using the RIPA Lysis and Extraction Buffer (Thermo Fisher Scientific). Halt Protease Inhibitor Cocktail $100 \times$ was added to the buffer before homogenization. The ratio was $57 \mathrm{mg}$ of tissue to $1 \mathrm{~mL}$ of RIPA buffer. The homogenates were incubated for $15 \mathrm{~min}$ with constant mixing and then centrifuged at $14,000 \times g$ and $4^{\circ} \mathrm{C}$ for $10 \mathrm{~min}$. Throughout the process, samples were continually kept on ice or at $4^{\circ} \mathrm{C}$. The resulting supernatants containing total proteins were assayed to determine protein concentrations against BSA standards using a Pierce BCA Protein Assay Kit (Thermo Fisher Scientific). The supernatants were aliquoted and stored at $-80^{\circ} \mathrm{C}$ until analysis.

Semiquantitative measurements of STAT3 phosphorylated at Tyr705 and total STAT3 proteins in total RIPA tissue lysates were performed using a STAT3 $(\mathrm{pY} 705)+$ Total ELISA Kit (Abcam, Toronto, ON, Canada) according to the manufacturer's instructions (http://www.abcam.com/ps/products/176/ab176666/ documents/ab176666\%20STAT3\%20pY705\%20Total \%20SimpleStep\%20ELISA \%20Kit\%20v5\%20(website) .pdf). Linearity and recovery experiments were performed to validate the detection of STAT3 in bovine lysates and to determine the total cellular protein concentration suitable for the analysis [300 and $150 \mu \mathrm{g} / \mathrm{mL}$ for STAT3 (pY705) and STAT3 (total), respectively].

Semiquantitative measurements of STAT5 A and STAT5 B (collectively known as STAT5 A/B) phosphorylated at Tyr694 and Tyr699, respectively, and total STAT5 A/B proteins in total RIPA tissue lysates were performed using a STAT5 A/B (pY694/699 + Total) ELISA Kit (Abcam) according to the manufacturer's instructions (http://www.abcam.com/ps/products/ 205/ab205715/documents/ab205715\%20STAT5\%20 AB \% 20pY694\%20699\%20Total\%20SimpleStep\%20 ELISA\%20Kit\%20v3\%20(website).pdf). Linearity and recovery experiments were performed to validate the detection of STAT5 A/B in bovine lysates and to determine the total cellular protein concentration suitable for the analysis [300 and $60 \mu \mathrm{g} / \mathrm{mL}$ for STAT5 A/B (pY694/699) and STAT5 A/B (total), respectively].

\section{Statistical Analysis}

Data were analyzed as a crossover design by ANOVA using the MIXED procedure of the SAS software package (version 9.0, SAS Institute Inc., Cary, NC). For variables with repeated measurements, the statistical model include treatment, day, period, treatment $\times$ day, and cow. Day was used as a repeated effect, and cow(treatment) was used as the subject. For variables without repeated measurement, the statistical model include treatment period and cow. The data from the pretreatment period ( $d-4$ to -1 ), those from the 
treatment period (d 1 to 7 ), and those from the posttreatment period ( 8 to 14 ) were analyzed separately. When available, means of the data from the pretreatment period were used as covariates. The amount of PRL released into the blood during milking was calculated by determining the area under the curve between 0 and 40 min relative to the start of milking, and basal PRL concentration was calculated by averaging the concentration obtained between -20 and 0 min. Differences were considered statistically significant when $P<$ 0.05 and a trend when $P<0.10$.

\section{RESULTS}

\section{DMI, Milk Yield, and Milk Composition}

The DMI was similar for both treatments during the pretreatment, treatment, and post-treatment periods (data not shown). Milk production was similar for CTL and E2 before the start of the experiment ( $\mathrm{d}-8$ and -1 ), averaging $39.9 \pm 0.38$ and $39.4 \pm 0.37 \mathrm{~kg} / \mathrm{d}$, respectively $(P=0.43$; Figure 1$)$. In the treatment period, milk production was greater during CTL treatment than during the E2 treatment $(39.9 \pm 0.47$ and $36.5 \pm 0.45 \mathrm{~kg} / \mathrm{d}$, respectively, $P<0.01)$. In the posttreatment period (d 8 to 14), milk production remained greater during CTL than during E2 $(36.9 \pm 0.87$ and $32.2 \pm 1.02 \mathrm{~kg} / \mathrm{d}$, respectively, $P=0.03)$.

We found no treatment $\times$ day interaction $(P>0.1)$ on milk fat content, which was not different before the treatments began $(P=0.96$; Table 2$)$. However, milk fat content tended $(P=0.08)$ to be greater during the treatment period and was greater during the posttreatment period $(P=0.03)$ when cows were treated with E2. Milk protein content was lower during E2 than during CTL in the pretreatment period $(P=0.02$; Figure 2A). We noted a treatment $\times$ day interaction $(P<0.01)$ on milk protein content during the treatment period. Milk protein content increased gradually during the E2 treatment and was greater during that treatment than during the CTL treatment on $\mathrm{d} 5$ to 7 $(P<0.01)$. Milk protein content remained greater in E2 than during CTL during the post-treatment period $(P<0.01)$. Milk lactose content tended to be lower $(P=0.10$; Figure $2 \mathrm{~B})$ during $\mathrm{E} 2$ in the pretreatment period. As was the case for milk protein content, milk lactose content increased gradually (treatment $\times$ day, $P<0.01)$ during the E2 treatment and was greater in that treatment than in the CTL treatment on d 5 to 7 $(P<0.01)$. Milk lactose content remained greater during E2 than during CTL in the post-treatment period $(P<0.01)$.

Fat yield was similar in both treatments during the pretreatment, treatment, and post-treatment periods (Table 2). Protein yield was similar for both treatments during the pre- and post-treatment periods, but was lower during E2 than during CTL in the treatment period $(P=0.04$; Table 2$)$. Lactose yield was similar for both treatments during the pre- and post-treatment periods but was lower during E2 than during CTL in the treatment period $(P=0.02$; Table 2$)$. Milk BSA concentrations were not different before and after the treatment period, but tended $(P=0.09)$ to be increased by E2 during the treatment period (Figure 2C).

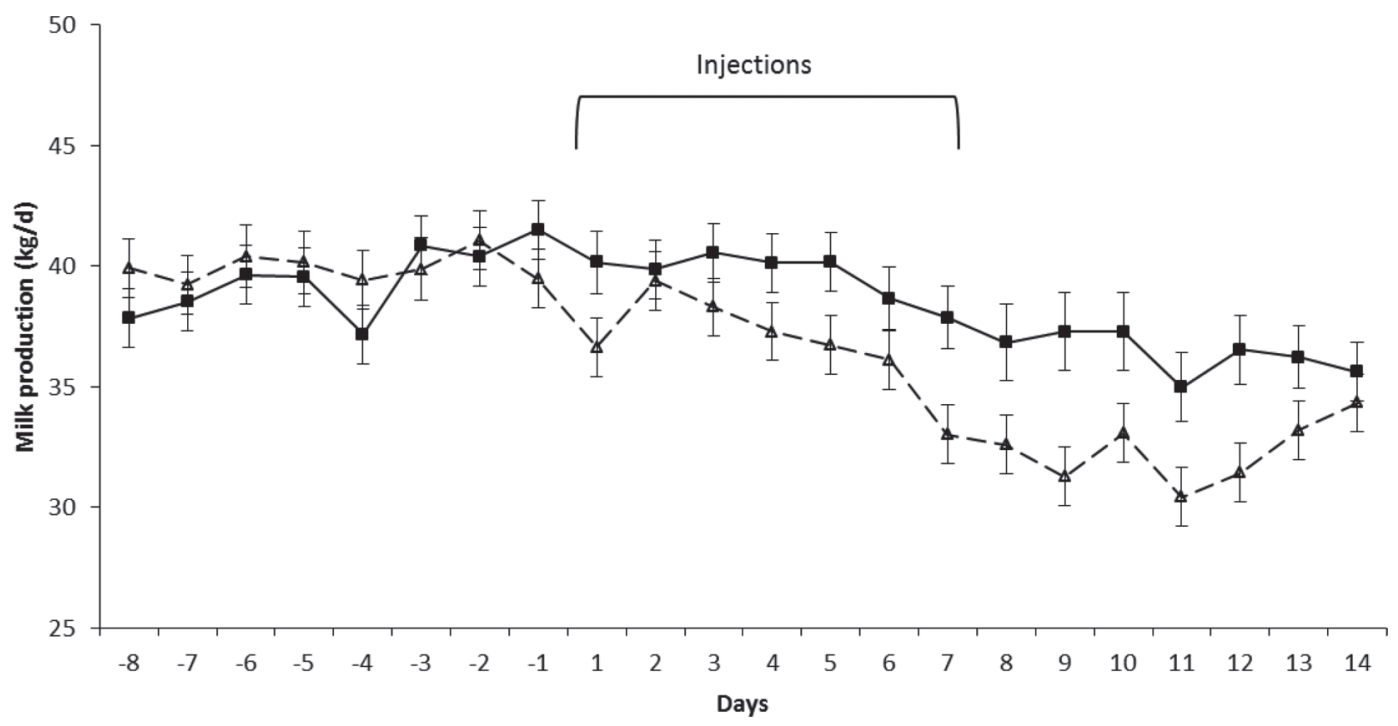

Figure 1. Daily milk yield of dairy cows injected daily with $17 \beta$-estradiol $(2.5 \mathrm{mg}, \Delta$ dashed line; $\mathrm{n}=7)$ or soy oil $(2.5 \mathrm{~mL}$, control, $\mathbf{\square}$ solid line; $\mathrm{n}=7)$ from $\mathrm{d} 1$ to 7 . Data are presented as LSM \pm SEM. Milk production was decreased by estradiol injections during the treatment $(P$ $<0.01)$ and post-treatment $(P=0.03)$ periods. 


\section{Hormones}

Plasma E2 was similar for the 2 treatments during the pretreatment period (Figure 3A). As expected, E2 injection increased $(P<0.001)$ the E2 concentration by about 3 fold during the treatment period. Although E2 concentration declined in the E2 group during the post-treatment period, that concentration was still greater than that of the CTL group $7 \mathrm{~d}$ after the end of injections $(P=0.01)$.

Plasma IGF-1 concentration was similar for the 2 treatments during the pre- and post-treatment periods, but was increased by E2 during the treatment period $(P<0.01$; Figure 3B). Serum cortisol concentration was not affected by the treatments during the pretreatment and treatment periods; however, a tendency was observed for greater cortisol concentration during E2 in the post-treatment period $(P=0.07$; Figure $3 \mathrm{C})$.

Serum PRL concentration was similar for both treatments before the treatments began $(P=0.2$; Figure $4 \mathrm{~A})$. During the treatment period, PRL concentration was greater during E2 than during CTL $(P=0.02)$. The concentration of PRL remained greater during the E2 in the post-treatment period $(P=0.02)$.

Milk PRL concentration was similar for both treatments before the treatments began $(P=0.4$; Figure 4B). Milk PRL concentration tended to be increased by E2 during the treatment period $(P=0.10)$. In the post-treatment period, we found no effect of treatments on milk PRL concentration $(P=0.12)$.

Milking-induced PRL release (Table 3) was measured before $(\mathrm{d}-4)$ and during (d 2 and 7 ) the treatment period, as well as during manual stimulation on $\mathrm{d} 7$. Basal PRL concentration was not affected by the treatments on $\mathrm{d}-4$ but was greater when cows received E2 during the treatment period $(P=0.04)$. The amount of PRL release induced by milking (area under the curve above baseline) was greater during $\mathrm{E} 2$ on $\mathrm{d}-4(P=$ 0.04). However, the amount of PRL release on $d 2$ and 7 and during manual stimulation was not affected by the treatments. Accordingly, peak PRL concentration tended to be greater during E2 on d $-4(P=0.06)$, but was not affected by the treatments on $\mathrm{d} 2$ or 7 or during manual stimulation.

\section{Mammary Gland}

The analysis of mRNA extracted from the mammary biopsies showed no effects of the treatments on expression of most of the tested genes. Lower mRNA levels of Bcl2 $(P=0.03)$ and a higher Bax:Bcl2 ratio $(P=$ 0.04 ) were observed in the mammary biopsies collected during the E2 treatment (Table 4 ). In addition, mRNA level of STAT5a was increased $(P=0.05)$ and that of STAT5b tended to be increased $(P=0.06)$ during E2 treatment.

The analysis of mRNA extracted from milk fat showed no difference before the treatments began (Supplemental Table S1; https://doi.org/10.3168/jds .2017-13353). The mRNA levels of genes related to PRL signaling (long and short isoforms of PRLR and $S O C S$ ) and to mammary activity ( $\alpha-\mathrm{LA}, \beta-\mathrm{CN}$, and acetyl-CoA carboxylase) were not affected by the treatments (Supplemental Table S1). However, E2 tended $(P=0.06)$ to reduce $A C A C A$ mRNA during the posttreatment period.

Quantification of the number of PRLR on mammary biopsies by Western blotting did not reveal any effect of treatments (data not shown). Similarly, the contents of total and phosphorylated STAT3 were not affected by the treatments (Table 5). However, the mammary tissue content of total STAT5 protein was markedly elevated by E2 $(P<0.001$; Table 5$)$. Nevertheless, the content of phosphorylated STAT5 was not affected by the treatments, such that the proportion of activated STAT5 tended $(P=0.06)$ to be lower during the E2 treatment.

\section{DISCUSSION}

Estradiol injection moderately decreased milk production in our study, with the decrease reaching $18 \%$

Table 2. Effect of daily injections of $17 \beta$-estradiol $(2.5 \mathrm{mg} ; \mathrm{n}=7)$ or soy oil $(2.5 \mathrm{~mL}$; control; $\mathrm{n}=7)$ for $7 \mathrm{~d}$ on milk composition and yield in mid-lactation cows ${ }^{1,2}$

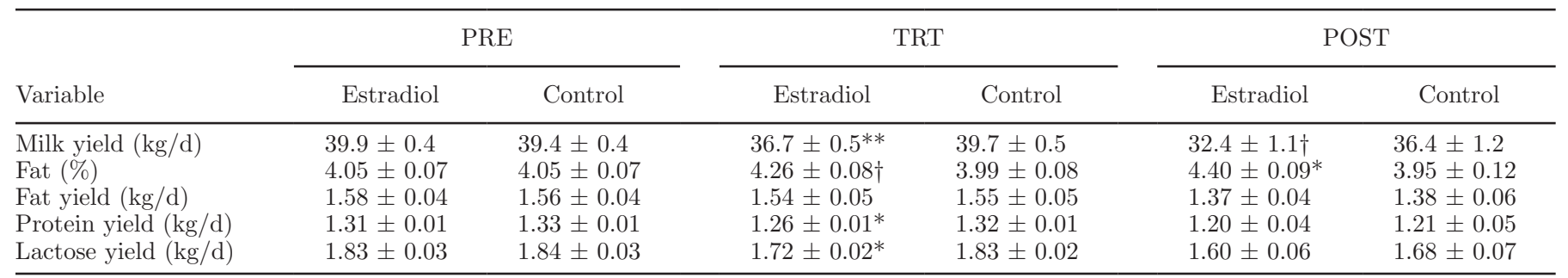

${ }^{1}$ Data are presented as LSM \pm SEM.

${ }^{2} \mathrm{PRE}=$ pretreatment period, $\mathrm{d}-4$ to -1 ; TRT $=$ treatment period, $\mathrm{d} 1$ to 7 ; POST $=$ post-treatment period, $\mathrm{d} 8$ to 14. $\dagger P<0.10 ;{ }^{*} P<0.05 ;{ }^{*} P<0.01$ : Values within a sampling day followed by different symbols differ. 
A

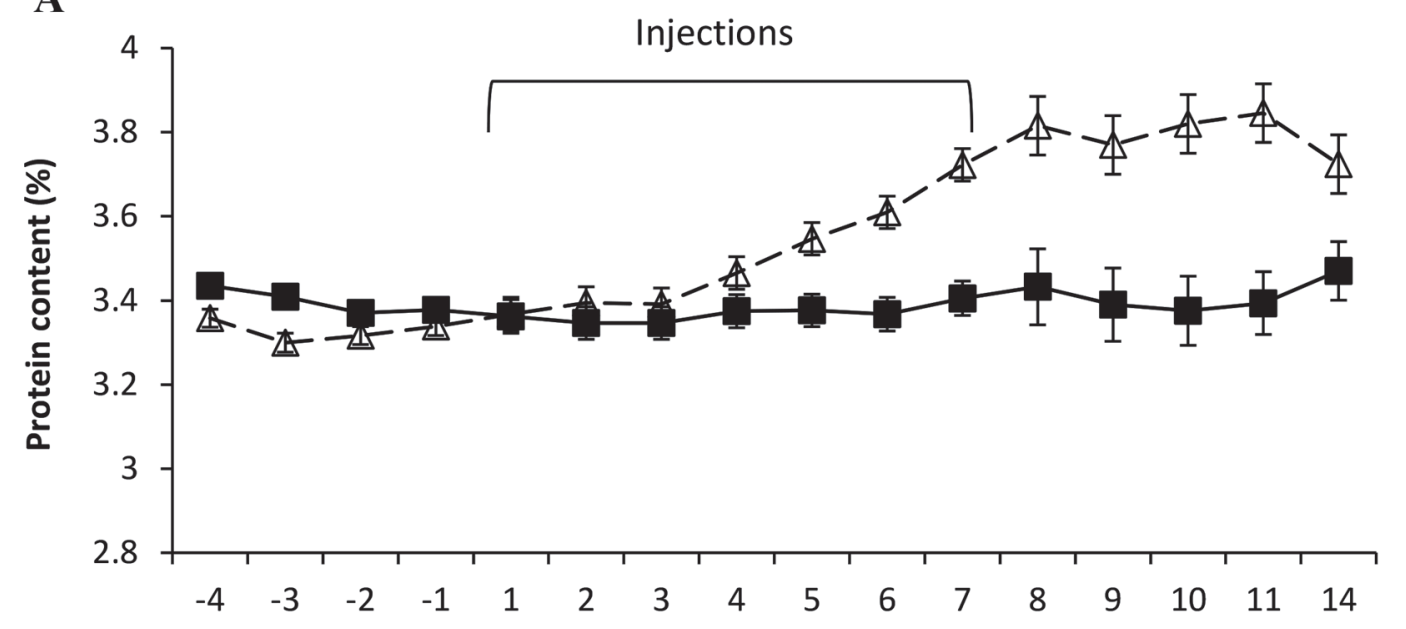

B
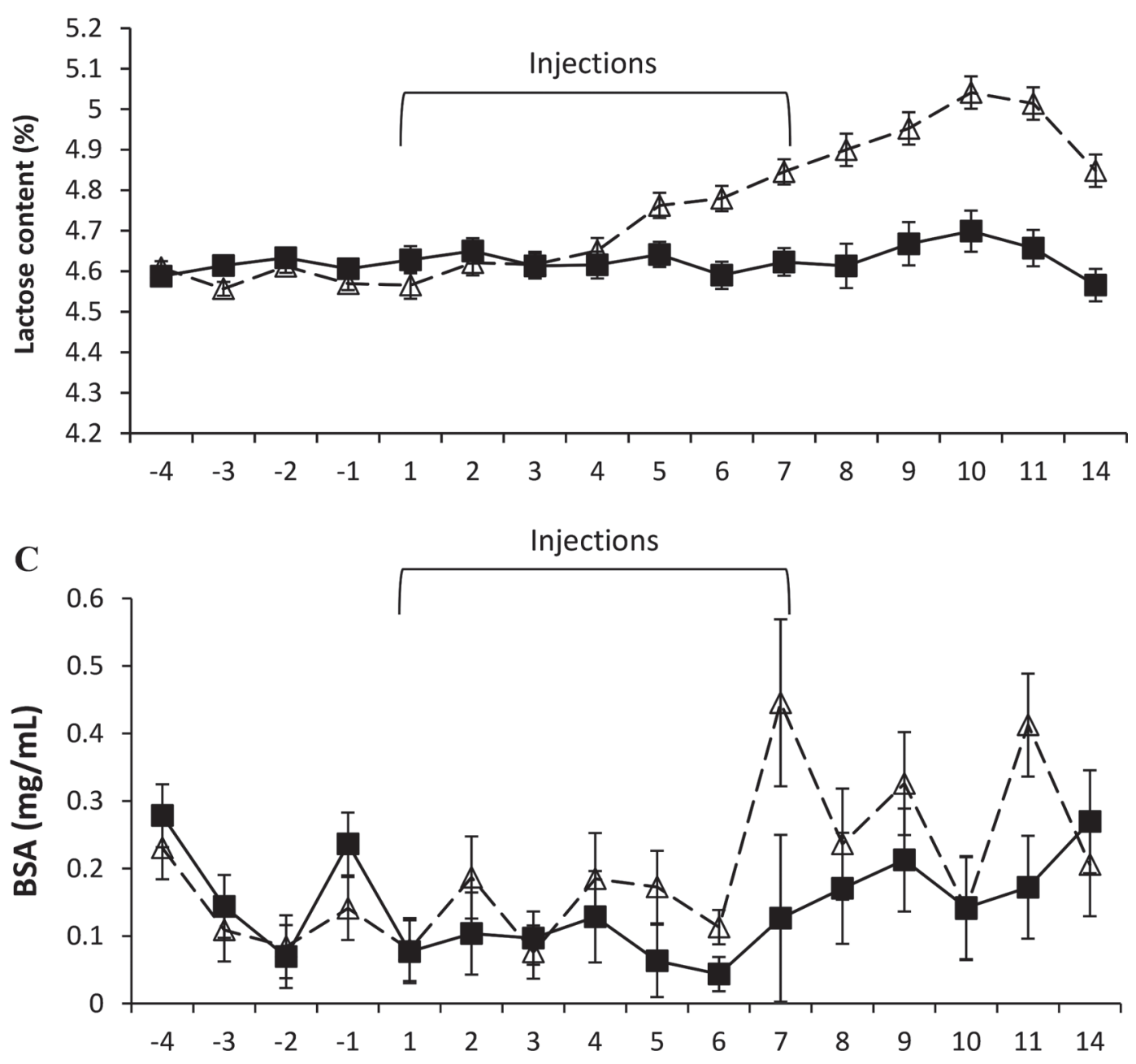

Figure 2. Milk protein content (A), lactose content (B), and BSA (C) of dairy cows injected daily with 17ß-estradiol (E2; $\Delta$ dashed line; $\mathrm{n}=7$ ) or soy oil (CTL, $\mathbf{\square}$ solid line; $\mathrm{n}=7$ ) from d 1 to 7 . Data are presented as LSM \pm SEM. Milk protein and lactose content were greater during E2 than during CTL from d 5 to 7 of the treatment period and during the post-treatment period $(P<0.01)$. Milk BSA concentrations tended $(P=0.09)$ to be increased by E2 during the treatment period. 

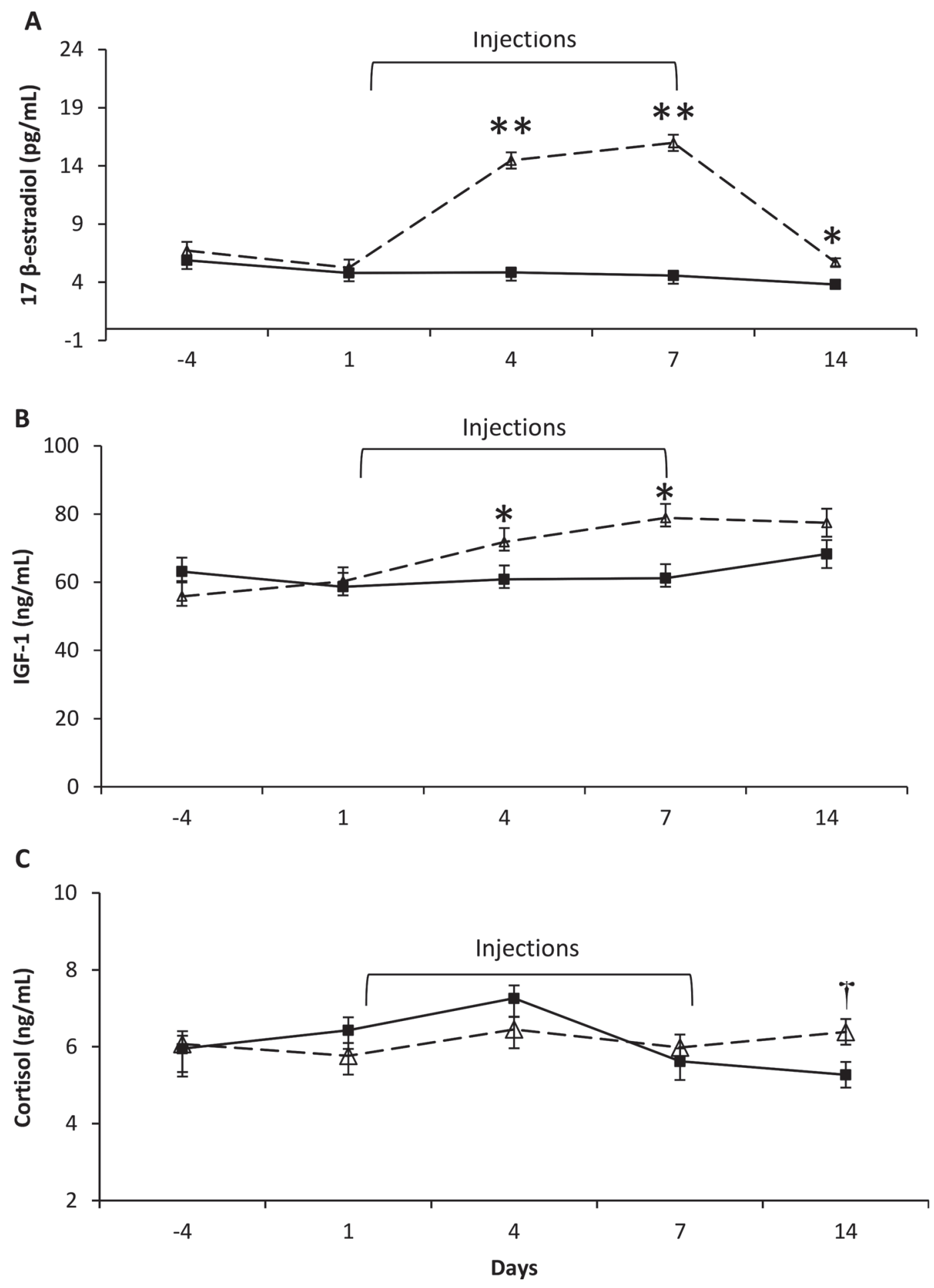

Figure 3. Concentrations of $17 \beta$-estradiol (A), IGF-1 (B), and cortisol (C) of dairy cows injected daily with $17 \beta$-estradiol (2.5 mg, $\triangle$ dashed line; $\mathrm{n}=7)$ or soy oil $(2.5 \mathrm{~mL}$, control, $\mathbf{\square}$ solid line; $\mathrm{n}=7)$ from $\mathrm{d} 1$ to 7 . Data are presented as $\mathrm{LSM} \pm \mathrm{SEM}$. $\dagger P<0.10 ;{ }^{*} P<0.05 ;{ }^{* *} P<$ 0.01 , values within a sampling day followed by different symbols differ.

at the end of the treatment period. In comparison, Delbecchi et al. (2005) found that injecting nonpregnant cows with $15 \mathrm{mg}$ of $\mathrm{E} 2$ per day for $8 \mathrm{~d}$ reduced milk production dramatically ( $81.6 \%$ on d 11). Similarly, Athie et al. (1996) reported that the administration of $15 \mathrm{mg}$ of $\mathrm{E} 2$ per day at drying off also abruptly 
decreased milk production (59\% after 3 injections). Furthermore, Mollett et al. (1976) reported that milk production decreased from $14 \mathrm{~kg}$ on d 0 to $4 \mathrm{~kg}$ on d 18 when cows were injected with very high doses of E2 (about $60 \mathrm{mg} / \mathrm{d}$ ) and progesterone (about $150 \mathrm{mg} / \mathrm{d}$ ) for $8 \mathrm{~d}$. In the present study, the dose used for E2 injection was only $2.5 \mathrm{mg} / \mathrm{d}$ and the concentration of E2 in the blood of E2-injected cows was within the normal physiological range for pregnant cows (Patel et al., 1995). This probably explains the moderate effects of E2 on milk production; nevertheless, this rate of decline is probably more representative of the gradual decline observed in pregnant cows.

In the present study, E2 significantly increased milk protein and lactose content. Mollett et al. (1976) reported that milk from nonpregnant cows that received injections of E2 and progesterone had greater fat and protein contents but lower lactose content. The administration of $\mathrm{E} 2$ to late-lactation cows was also found to increase milk protein content (Athie et al., 1996). Additionally, Delbecchi et al. (2005) showed that E2 decreased milk fat and lactose contents and increased milk protein content. Nevertheless, in all those experiments, the yields of lactose and protein were decreased. The increase in component concentration is therefore related to a greater reduction in milk volume rather than increased synthesis of these components. The reduction in lactose concentration in some studies is probably related to the fact that pharmacologic doses of E2 induce an opening of the tight junctions, as indicated by increases in the milk $\mathrm{Na}^{+}$-to- $\mathrm{K}^{+}$ratio (Peaker and Linzell, 1974; Athie et al., 1996) and in blood lactose concentration (Gulay et al., 2009).

Estradiol increased the basal serum concentration of PRL but had no significant effect on milking-induced PRL release. In previous studies, injections of E2 caused 2- to 5-fold increases in plasma PRL concentration in cattle (Schams and Karg, 1972; Schams et al., 1974).

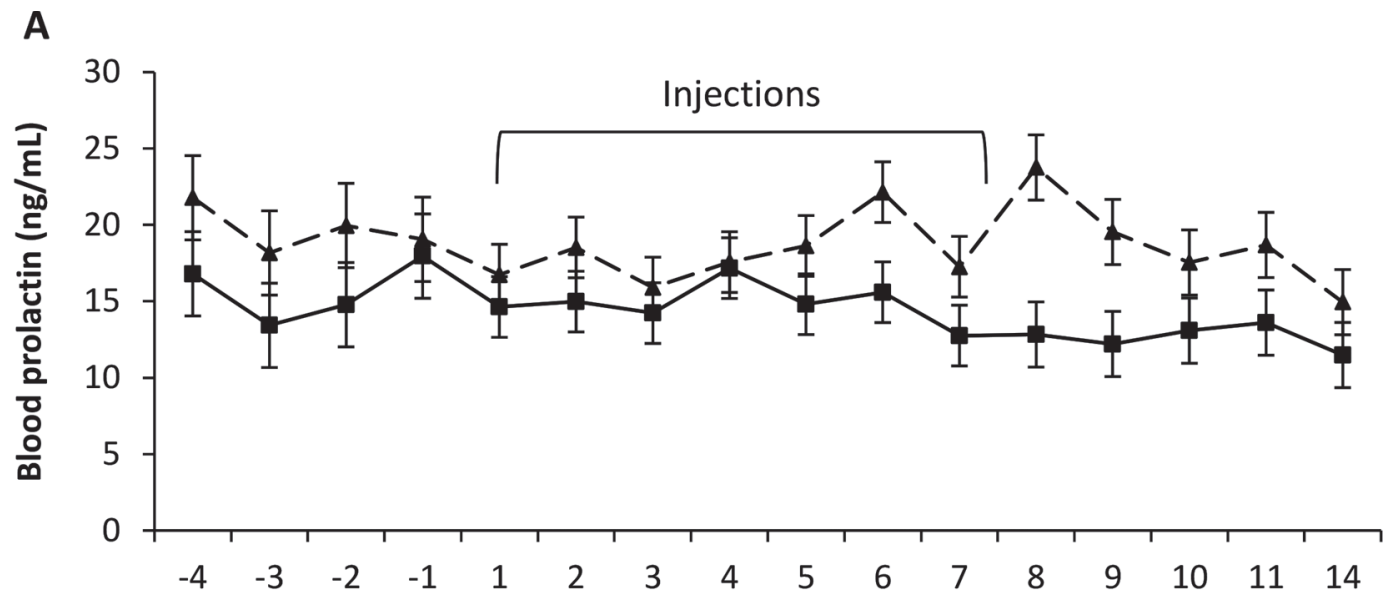

B

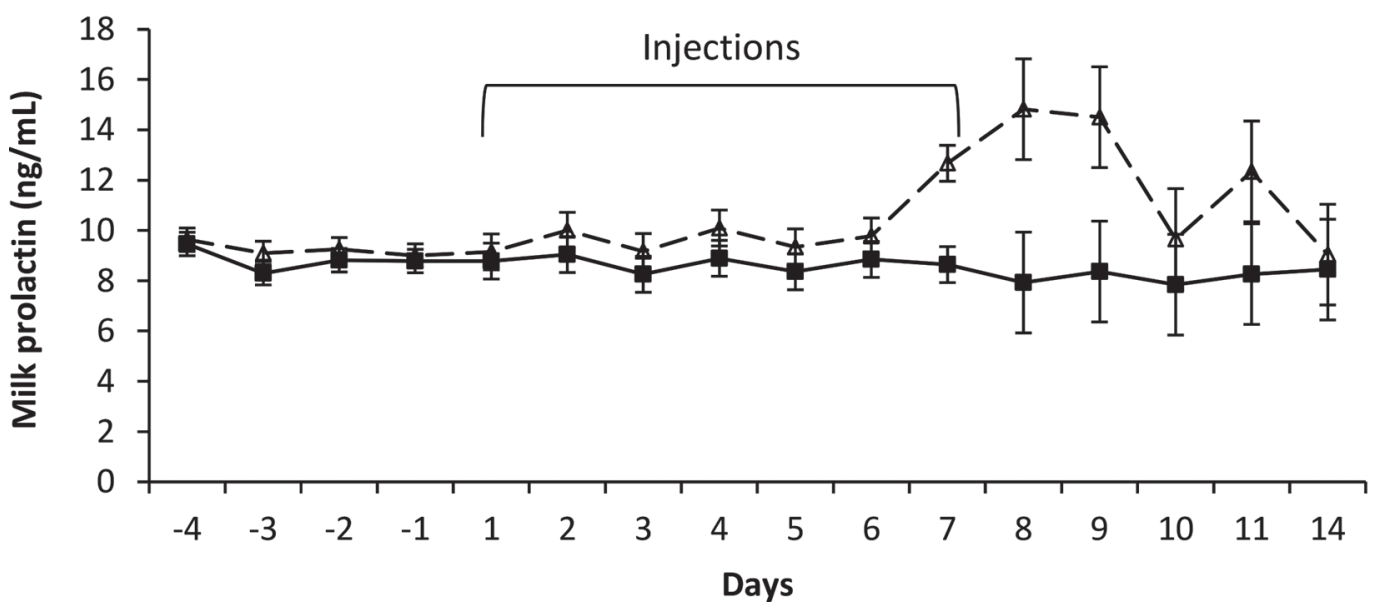

Figure 4. Basal concentration of prolactin in blood (A) and milk (B) of dairy cows injected daily with $17 \beta$-estradiol $(2.5 \mathrm{mg}, \Delta$ dashed line; $\mathrm{n}=7)$ or soy oil $(2.5 \mathrm{~mL}$, control, $\mathbf{a}$ solid line; $\mathrm{n}=7)$ from d 1 to 7 . Data are presented as LSM \pm SEM. Blood prolactin was greater when cows were treated with estradiol during the treatment and post-treatment periods $(P=0.02)$. 


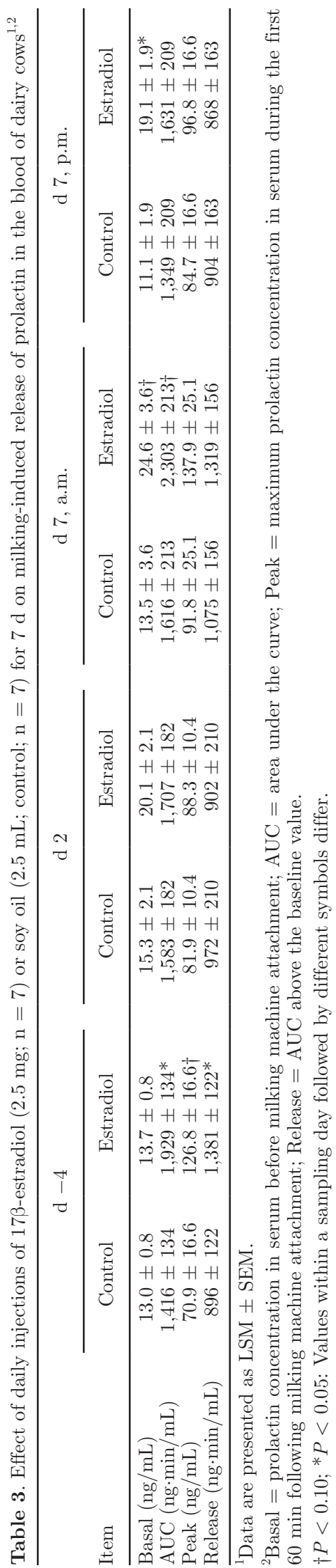

The main physiological control of PRL secretion is by the tuberoinfundibular dopamine (TIDA) pathway of the hypothalamus via the inhibitory action of dopamine (Li et al., 1999; Freeman et al., 2000). In addition, PRL is normally tightly regulated by a short-loop negative feedback mechanism, whereby PRL increases dopamine secretion (Grattan et al., 2008), which inhibits PRL secretion. Cramer et al. (1979) indicated that an acute effect of E2 is the suppression of the hypothalamic secretion of dopamine into hypophysial portal blood in rats. Furthermore, dopamine neurons of the tuberoinfundibular system and of the incertohypothalamic system are target cells for estrogen, as estradiol is concentrated in their nucleus (Sar, 1984). Although explicit evidence is lacking, it is reasonable to assume that E2 enhances PRL secretion by suppressing the hypothalamic secretion of dopamine. Nevertheless, E2 has also been reported to inhibit PRL secretion by the lactotroph cells (Raymond et al., 1978). An obvious conclusion is that E2 does not inhibit milk production through an inhibition of PRL secretion.

Estradiol injections significantly increased IGF-1 concentration. It has been reported that transdermal E2 administration increased circulating IGF-1 in postmenopausal women (Weissberger et al., 1991). In ovariectomized cows, E2 have been reported to enhance plasma GH and IGF-1 as well as the liver expression of the GH receptor and IGF-1 mRNA, which suggests that E2 affects the hypothalamo-pituitary-liver axis in cows (Colak et al., 2011). Generally, IGF-1 is considered as a galactopoietic hormone and has been shown to increase milk secretion in goats (Prosser et al., 1990);

Table 4. Effect of the daily injection of dairy cows with 173 -estradiol $(2.5 \mathrm{mg} ; \mathrm{E} 2 ; \mathrm{n}=7)$ or soy oil $(2.5 \mathrm{~mL}$; control, CTL; $\mathrm{n}=7)$ for $7 \mathrm{~d}$ on mRNA levels in mammary gland biopsies collected at the end of each treatment period

\begin{tabular}{lcccc}
\hline Gene & CTL & E2 & SEM & $P$-value \\
\hline CSN2 & 0.50 & 0.40 & 0.06 & 0.30 \\
LALBA & 0.50 & 0.40 & 0.07 & 0.35 \\
CASP3 & 0.83 & 0.73 & 0.08 & 0.38 \\
ACACA & 1.11 & 1.00 & 0.10 & 0.47 \\
Bax & 0.94 & 1.02 & 0.03 & 0.13 \\
Bcl2 & 0.90 & 0.65 & 0.06 & 0.03 \\
Bax/Bcl2 & 1.20 & 1.60 & 0.11 & 0.04 \\
PRLR (long) & 0.60 & 0.85 & 0.10 & 0.13 \\
PRLR (short) & 0.73 & 1.03 & 0.13 & 0.16 \\
GHR & 0.94 & 1.13 & 0.07 & 0.12 \\
SOCS2 & 1.06 & 0.86 & 0.14 & 0.37 \\
SOCS3 & 0.96 & 1.89 & 0.23 & 0.51 \\
STAT5a & 0.66 & 1.05 & 0.11 & 0.05 \\
STAT5b & 0.50 & 1.13 & 0.18 & 0.06 \\
\hline
\end{tabular}

${ }^{1}$ Statistical analyses were performed on the ratio of each gene relative to the geometric mean of GAPDH and UXT. Data were analyzed after transformation of cycle threshold values using a relative standard curve. 
therefore, it is unlikely that the E2-induced decrease in milk production was mediated by IGF-1.

During the post-treatment period, we noted a trend for greater cortisol concentration. A previous study showed that the E2 level reached its highest point at the peak estrous behavior score and that this highest level was accompanied by a slight increase in cortisol level (Lyimo et al., 2000). Glucocorticoid administration was also reported to inhibit milk production in both rodents and cows (Shamay et al., 2000; Vilela and Giusti-Paiva, 2011). However, the slightly greater cortisol concentration in the E2 treatment was more the result of the decline in cortisol concentration in the CTL group on $\mathrm{d}$ 14 than the result of an enhanced concentration caused by E2. Therefore, glucocorticoids do not appear to be involved in the E2-induced decrease in milk production.

Despite the fact that we were not able to show the direct effect of E2 on mammary proliferation and apoptosis, we found that the expression of the Bcl2 gene in the mammary gland was decreased by E2, whereas the $B a x: B c l 2$ ratio was enhanced by it. Bax belongs to the $B c l 2$ family, which plays a central role in the balance of events leading to cell death or survival (Adams and Cory, 1998). The differential rate of expression of Bax (proapoptotic) and Bcl2 (antiapoptotic) is often used as an indicator of cell susceptibility to apoptosis (Perlman et al., 1999; Nørgaard et al., 2008), including in the mammary gland (Andres and Strange, 1999; Long et al., 2001). The decline in milk production after the peak of lactation is due to the loss of secretory cells (Knight, 1993; Capuco et al., 2001) through apoptosis (Wilde et al., 1997). Given that gestation accelerates the decline in milk production, the enhancement of secretory cell apoptosis by E2 is not unexpected.

As PRL is a galactopoietic hormone in cows (Lacasse et al., 2016), we hypothesized that the inhibition of milk synthesis by E2 could be mediated by a decrease in mammary gland responsiveness to PRL in dairy cows. In rats, Nolin and Bogdanove (1980) demonstrated that the repression of lactation induced by E2 is due to diminished mammary gland responsiveness rather than decreased PRL secretion. However, the expression of the long isoform of PRLR and the number of PRLR evaluated by Western blotting were not affected by E2 injections in the present study. This finding suggests that E2 does not inhibit milk production by downregulating the number of PRL receptors.

Estradiol could also affect PRL signaling downstream of the receptor. The binding of PRL to the long isoform of PRLR activates STAT5, a key intracellular mediator of PRL signaling that can activate the transcription of milk proteins in response to PRL (Lesueur et al., 1991). Although we found a trend for a lower proportion of activated STAT5 in the present study, this is essentially due to the fact that E2 markedly elevated the concentration of the STAT5 protein. Accordingly, gene expression of STAT5a was elevated and that of STAT5b tended to be elevated by E2. Santos et al. (2008) also reported that E2 induces STAT5 gene expression in mouse mammary tissue. Suppressors of cytokine signaling are known to interfere with PRL signaling (Sutherland et al., 2007) intracellularly. Estrogen has been shown to inhibit JAK/STAT signaling by GH via the induction of SOCS-2, a protein inhibitor for cytokine signaling (Leung et al., 2003); however, we did not observe any effect of E2 on the expression of SOCS2 and SOCS3. Accordingly, the expression of the milk protein genes $C S N 2$ and $L A L B A$ were not affected by the treatments. The $\mathrm{P} 13 \mathrm{~K} / \mathrm{AKT}$ pathway is also activated by both long and short isoforms of PRLR (Binart et al., 2010); interestingly, this pathway has also been reported to be modulated by E2 in the mammary parenchyma of prepubertal heifers (Connor et al., 2007) and probably deserves further investigation.

In conclusion, we found that exogenous E2 inhibited milk synthesis despite increased basal PRL concentration without any modification of PRL release at milking. Reduced milk synthesis was not associated with

Table 5. Effect of the daily injection of dairy cows with $17 \beta$-estradiol $(2.5 \mathrm{mg} ; \mathrm{E} 2 ; \mathrm{n}=7)$ or soy oil $(2.5$ $\mathrm{mL}$; control, CTL; $\mathrm{n}=7$ ) for $7 \mathrm{~d}$ on signal transducer and activator of transcription 3 (STAT3) and signal transducer and activator of transcription 5 (STAT5) levels in mammary gland biopsies collected at the end of each treatment period ${ }^{1}$

\begin{tabular}{|c|c|c|c|c|}
\hline Genes & CTL & $\mathrm{E} 2$ & SEM & $P$-value \\
\hline Phosphorylated STAT3 $\left(\mathrm{AU}^{2}\right)$ & 3.73 & 3.84 & 0.31 & 0.81 \\
\hline Total STAT3 (AU) & 13.28 & 13.63 & 1.07 & 0.82 \\
\hline STAT3 activation ${ }^{3}(\%)$ & 30.82 & 30.99 & 5.46 & 0.98 \\
\hline Phosphorylated STAT5 (AU) & 5.89 & 8.29 & 0.99 & 0.15 \\
\hline Total STÄT5 (AU) & 18.23 & 42.33 & 2.2 & 0.0006 \\
\hline STAT5 activation ${ }^{4}(\%)$ & 31.82 & 19.71 & 3.49 & 0.06 \\
\hline
\end{tabular}

${ }^{1}$ Data are presented as LSM.

${ }^{2} \mathrm{AU}=$ arbitrary units.

${ }^{3}$ Calculated as (phosphorylated STAT3/total STAT3) $\times 100$.

${ }^{4}$ Calculated as (phosphorylated STAT5/total STAT5) $\times 100$. 
downregulation of the long isoform of PRLR, decreased activation of STAT5, or increased expression of SOCS. Even though this finding needs to be further confirmed, the present data suggest that E2 could inhibit milk production through pathways other than the inhibition of PRL secretion or mammary gland responsiveness to this hormone.

\section{ACKNOWLEDGMENTS}

The authors thank the following people from Sherbrooke R\&D Centre (Sherbrooke, QC, Canada): Catherine Thibault, Séverine Ollier, Shirley Caron, and Veronique Roy for providing technical assistance; and the dairy barn staff for taking care of the cows and helping with the blood sampling. The authors are grateful to Mary Varcoe, from the Translation Bureau, Public Services and Procurement Canada (Ottawa, ON, Canada), for her careful editing of this manuscript. The authors also thank the National Hormone and Peptide Program (Torrance, CA) and A. F. Parlow for providing the bovine PRL and antibodies. This research was financially supported by Agriculture and Agri-Food Canada, the National Sciences and Engineering Research Council of Canada (Ottawa, ON, Canada), and Dairy Farmers of Canada (Ottawa, ON, Canada). Jinjin Tong was supported by a scholarship from the Chinese Scholarship Council (Beijing, China).

\section{REFERENCES}

Adams, J. M., and S. Cory. 1998. The Bcl-2 protein family: Arbiters of cell survival. Science 281:1322-1326.

Andersen, C. L., J. L. Jensen, and T. F. Ørntoft. 2004. Normalization of real-time quantitative reverse transcription-PCR data: A model-based variance estimation approach to identify genes suited for normalization, applied to bladder and colon cancer data sets. Cancer Res. 64:5245-5250.

Andres, A.-C., and R. Strange. 1999. Apoptosis in the estrous and menstrual cycles. J. Mammary Gland Biol. Neoplasia 4:221-228.

Applied Biosystems. 1997. Applied Biosystems, ABI PRISM 7700 Sequence Detection System. User bulletin \#2. Applied Biosystems, Foster City, CA.

Athie, F., K. C. Bachman, H. H. Head, M. J. Hayen, and C. J. Wilcox. 1996. Estrogen administered at final milk removal accelerates involution of bovine mammary gland. J. Dairy Sci. 79:220-226.

Auldist, M. J., S.-A. Turner, C. D. McMahon, and C. G. Prosser. 2007. Effects of melatonin on the yield and composition of milk from grazing dairy cows in New Zealand. J. Dairy Res. 74:52-57.

Bachman, K. C., M. J. Hayen, D. Morse, and C. J. Wilcox. 1988 Effect of pregnancy, milk yield, and somatic cell count on bovine milk fat hydrolysis. J. Dairy Sci. 71:925-931.

Bernier-Dodier, P., C. L. Girard, B. G. Talbot, and P. Lacasse. 2011. Effect of dry period management on mammary gland function and its endocrine regulation in dairy cows. J. Dairy Sci. 94:4922-4936.

Bilodeau, P. P., D. Petitclerc, N. St. Pierre, G. Pelletier, and G. J. St. Laurent. 1989. Effects of photoperiod and pair-feeding on lactation of cows fed corn or barley grain in total mixed rations. J. Dairy Sci. 72:2999-3005.
Binart, N., A. Bachelot, and J. Bouilly. 2010. Impact of prolactin receptor isoforms on reproduction. Trends Endocrinol. Metab. $21: 362-368$.

Boutinaud, M., V. Lollivier, L. Finot, R. M. Bruckmaier, and P. Lacasse. 2012. Mammary cell activity and turnover in dairy cows treated with the prolactin-release inhibitor quinagolide and milked once daily. J. Dairy Sci. 95:177-187.

Brosseau, J.-P., J.-F. Lucier, E. Lapointe, M. Durand, D. Gendron, J. Gervais-Bird, K. Tremblay, J.-P. Perreault, and S. A. Elela. 2010. High-throughput quantification of splicing isoforms. RNA 16:442-449. https://doi.org/10.1261/rna.1877010.

Canadian Council on Animal Care. 1993. Guide to the care and use of experimental animals. Vol. 1. 2nd ed. E. D. Olfert, B. M. Cross, and A. A. McWilliam, ed. CCAC, Ottawa, ON, Canada.

Cánovas, A., G. Rincon, C. Bevilacqua, A. Islas-Trejo, P. Brenaut, R. C. Hovey, M. Boutinaud, C. Morgenthaler, M. K. VanKlompenberg, P. Martin, and J. F. Medrano. 2014. Comparison of five different RNA sources to examine the lactating bovine mammary gland transcriptome using RNA-Sequencing. Sci. Rep. 4:5297.

Capuco, A. V., D. L. Wood, R. Baldwin, K. Mcleod, and M. J. Paape. 2001. Mammary cell number, proliferation, and apoptosis during a bovine lactation: Relation to milk production and effect of bST. J. Dairy Sci. 84:2177-2187.

Colak, M., T. Shimizu, N. Matsunaga, C. Murayama, S. Nagashima, M. Kataoka, C. Kawashima, M. Matsui, H. A. van Dorland, and R. Bruckmaier. 2011. Oestradiol enhances plasma growth hormone and insulin-like growth factor-I concentrations and increased the expression of their receptors mRNAs in the liver of ovariectomized cows. Reprod. Domest. Anim. 46:854-861.

Connor, E. E., M. J. Meyer, R. W. Li, M. E. Van Amburgh, Y. R. Boisclair, and A. V. Capuco. 2007. Regulation of gene expression in the bovine mammary gland by ovarian steroids. J. Dairy Sci. 90(Suppl 1):E55-E65.

Cramer, O. M., R. C. Parker Jr., and J. C. Porter. 1979. Estrogen inhibition of dopamine release into hypophysial portal blood. Endocrinology 104:419-422.

de Lima, L. S., E. Martineau, F. E. De Marchi, M.-F. Palin, G. T. dos Santos, and H. V. Petit. 2016. A new technique for repeated biopsies of the mammary gland in dairy cows allotted to Latin-square design studies. Can. J. Vet. Res. 80:225-229.

Delbecchi, L., N. Miller, C. Prud'homme, D. Petitclerc, G. F. Wagner, and P. Lacasse. 2005. 17ß-estradiol reduces milk synthesis and increases stanniocalcin gene expression in the mammary gland of lactating cows. Livest. Sci. 98:57-66.

Dudemaine, P. L., C. Thibault, K. Alain, and N. Bissonnette. 2014 Genetic variations in the SPP1 promoter affect gene expression and the level of osteopontin secretion into bovine milk. Anim. Genet. 45:629-640.

Eaton, S. L., S. L. Roche, M. L. Hurtado, K. J. Oldknow, C. Farquharson, T. H. Gillingwater, and T. M. Wishart. 2013. Total protein analysis as a reliable loading control for quantitative fluorescent western blotting. PLoS One 8:e72457.

Flint, D. J., and M. Gardner. 1994. Evidence that growth hormone stimulates milk synthesis by direct action on the mammary gland and that prolactin exerts effects on milk secretion by maintenance of mammary deoxyribonucleic acid content and tight junction status. Endocrinology 135:1119-1124.

Freeman, M. E., B. Kanyicska, A. Lerant, and G. Nagy. 2000. Prolactin: Structure, function, and regulation of secretion. Physiol. Rev. 80:1523-1631.

Gilda, J. E., and A. V. Gomes. 2013. Stain-Free total protein staining is a superior loading control to $\beta$-actin for Western blots. Anal. Biochem. 440:186-188.

Grattan, D. R., F. J. Steyn, I. C. Kokay, G. M. Anderson, and S. J. Bunn. 2008. Pregnancy-induced adaptation in the neuroendocrine control of prolactin secretion. J. Neuroendocrinol. 20:497-507.

Gulay, M. S., M. J. Hayen, H. H. Head, and K. C. Bachman. 2009. Short communication: Effect of estrogen supplemented at dry-off on temporal changes in concentrations of lactose in blood plasma of Holstein cows. J. Dairy Sci. 92:3815-3818. 
Kleinberg, D. L., J. Todd, and G. Babitsky. 1983. Inhibition by estradiol of the lactogenic effect of prolactin in primate mammary tissue: Reversal by antiestrogens LY 156758 and tamoxifen. Proc. Natl. Acad. Sci. USA 80:4144-4148.

Knight, C. 1993. Prolactin revisited. Pages 72-80 in Hannah Research Institute Yearbook. Hannah Research Institute, Ayr, UK.

Krebs, D. L., and D. J. Hilton. 2000. SOCS: Physiological suppressors of cytokine signaling. J. Cell Sci. 113:2813-2819.

Lacasse, P., V. Lollivier, R. M. Bruckmaier, Y. R. Boisclair, G. F. Wagner, and M. Boutinaud. 2011. Effect of the prolactin-release inhibitor quinagolide on lactating dairy cows. J. Dairy Sci. 94:1302-1309.

Lacasse, P., and S. Ollier. 2015. The dopamine antagonist domperidone increases prolactin concentration and enhances milk production in dairy cows. J. Dairy Sci. 98:7856-7864.

Lacasse, P., S. Ollier, V. Lollivier, and M. Boutinaud. 2016. New insights into the importance of prolactin in dairy ruminants. J. Dairy Sci. 99:864-874.

Lesueur, L., M. Edery, S. Ali, J. Paly, P. A. Kelly, and J. Djiane. 1991. Comparison of long and short forms of the prolactin receptor on prolactin-induced milk protein gene transcription. Proc. Natl. Acad. Sci. USA 88:824-828.

Leung, K. C., N. Doyle, M. Ballesteros, K. Sjogren, C. K. W. Watts, T. H. Low, G. M. Leong, R. J. M. Ross, and K. K. Y. Ho. 2003. Estrogen inhibits GH signaling by suppressing GH-induced JAK2 phosphorylation, an effect mediated by SOCS-2. Proc. Natl. Acad. Sci. USA 100:1016-1021.

Li, C., P. Chen, and M. S. Smith. 1999. Neuropeptide Y and tuberoinfundibular dopamine activities are altered during lactation: Role of prolactin. Endocrinology 140:118-123.

Lollivier, V., P. Lacasse, J. Angulo Arizala, P. Lamberton, S. Wiart, J. Portanguen, R. Bruckmaier, and M. Boutinaud. 2015. In vivo inhibition followed by exogenous supplementation demonstrates galactopoietic effects of prolactin on mammary tissue and milk production in dairy cows. J. Dairy Sci. 98:8775-8787.

Long, E., A. V. Capuco, D. L. Wood, T. Sonstegard, G. Tomita, M. J. Paape, and X. Zhao. 2001. Escherichia coli induces apoptosis and proliferation of mammary cells. Cell Death Differ. 8:808-816.

Lyimo, Z. C., M. Nielen, W. Ouweltjes, T. A. M. Kruip, and F. J. C. M. van Eerdenburg. 2000. Relationship among estradiol, cortisol and intensity of estrous behavior in dairy cattle. Theriogenology 53:1783-1795.

McCormack, J. T., and G. S. Greenwald. 1974. Progesterone and oestradiol-17 $\beta$ concentrations in the peripheral plasma during pregnancy in the mouse. J. Endocrinol. 62:101-107.

Mollett, T. A., R. E. Erb, E. L. Monk, and P. V. Malven. 1976. Changes in estrogen, progesterone, prolactin and lactation traits associated with injection of estradiol-17 $\beta$ and progesterone into lactating cows. J. Anim. Sci. 42:655-663.

Nolin, J. M., and E. M. Bogdanove. 1980. Effects of estrogen on prolactin (PRL) incorporation by lutein and milk secretory cells and on pituitary PRL secretion in the postpartum rat: Correlations with target cell responsiveness to PRL. Biol. Reprod. 22:393-416.

Nørgaard, J. V., P. K. Theil, M. T. Sørensen, and K. Sejrsen. 2008. Cellular mechanisms in regulating mammary cell turnover during lactation and dry period in dairy cows. J. Dairy Sci. 91:2319-2327.

Ollier, S., X. Zhao, and P. Lacasse. 2013. Effect of prolactin-release inhibition on milk production and mammary gland involution at drying-off in cows. J. Dairy Sci. 96:335-343.

Ollier, S., X. Zhao, and P. Lacasse. 2014. Effects of feed restriction and prolactin-release inhibition at drying off on metabolism and mammary gland involution in cows. J. Dairy Sci. 97:4942-4954.

Patel, O. V., N. Sasaki, M. Hirako, T. Takahashi, and I. Domeki. 1995. Sex steroid levels throughout gestation in cows carrying normal and malformed fetuses. J. Vet. Med. Sci. 57:659-663.

Peaker, M., and J. L. Linzell. 1974. The effects of oestrus and exogenous oestrogens on milk secretion in the goat. J. Endocrinol. 61:231-240.

Perlman, H., X. Zhang, M. W. Chen, K. Walsh, and R. Buttyan. 1999. An elevated bax/bcl-2 ratio corresponds with the onset of prostate epithelial cell apoptosis. Cell Death Differ. 6:48-54.
Peters, R. R., L. T. Chapin, R. S. Emery, and H. A. Tucker. 1981. Milk yield, feed intake, prolactin, growth hormone, and glucocorticoid response of cows to supplemented light. J. Dairy Sci. 64:1671-1678.

Prosser, C. G., I. R. Fleet, A. N. Corps, E. R. Froesch, and R. B. Heap. 1990. Increase in milk secretion and mammary blood flow by intraarterial infusion of insulin-like growth factor-I into the mammary gland of the goat. J. Endocrinol. 126:437-443.

Raymond, V., M. Bealieu, and F. Labrie. 1978. Potent antidopaminergic activity of estradiol at the pituitary level on prolactin release. Science 200:1173-1175

Santos, S. J., S. Z. Haslam, and S. E. Conrad. 2008. Estrogen and progesterone are critical regulators of Stat5a expression in the mouse mammary gland. Endocrinology 149:329-338.

Sar, M. 1984. Estradiol is concentrated in tyrosine hydroxylase-containing neurons of the hypothalamus. Science 223:938-940.

Schams, D., and H. Karg. 1972. The immediate response of the plasma prolactin level to oestrogen infusions in dairy cows. Acta Endocrinol. (Copenh.) 69:47-52

Schams, D., V. Reinhardt, and H. Karg. 1974. The immediate response of the plasma prolactin level to oestrogen and progesterone infusions in bulls. Acta Endocrinol. (Copenh.) 76:242-247.

Shamay, A., F. Shapiro, H. Barash, I. Bruckental, and N. Silanikove. 2000. Effect of dexamethasone on milk yield and composition in dairy cows. Ann. Zootech. 49:343-352.

Sutherland, K. D., G. J. Lindeman, and J. E. Visvader. 2007. Knocking off SOCS genes in the mammary gland. Cell Cycle 6:799-803.

Tankeyoon, M., N. Dusitsin, S. Chalapati, S. Koetsawang, S. Saibiang, M. Sas, J. J. Gellen, O. Ayeni, R. Gray, A. Pinol, and L. Zegers. 1984. Effects of hormonal contraceptives on milk volume and infant growth: WHO Special Programme of Research and Development and Research Training in Human Reproduction. Contraception 30:505-522.

Taylor, J. C., and M. Peaker. 1975. Effects of bromocriptine on milk secretion in the rabbit. J. Endocrinol. 67:313-314.

Teglund, S., C. McKay, E. Schuetz, J. M. van Deursen, D. Stravopodis, D. Wang, M. Brown, S. Bodner, G. Grosveld, and J. N. Ihle. 1998. Stat5a and Stat5b proteins have essential and nonessential, or redundant, roles in cytokine responses. Cell 93:841-850.

Thompson, I. M., M. Ozawa, J. W. Bubolz, Q. Yang, and G. E. Dahl. 2011. Bovine luteal prolactin receptor expression: Potential involvement in regulation of progesterone during the estrous cycle and pregnancy. J. Anim. Sci. 89:1338-1346.

Vilela, F. C., and A. Giusti-Paiva. 2011. Glucocorticoids disrupt neuroendocrine and behavioral responses during lactation. Endocrinology 152:4838-4845.

Weissberger, A. J., K. K. Y. Ho, and L. Lazarus. 1991. Contrasting effects of oral and transdermal routes of estrogen replacement therapy on 24-hour growth hormone (GH) secretion, insulin-like growth factor I, and GH-binding protein in postmenopausal women. J. Clin. Endocrinol. Metab. 72:374-381.

Wilde, C. J., L. H. Quarrie, E. Tonner, D. J. Flint, and M. Peaker. 1997. Mammary apoptosis. Livest. Prod. Sci. 50:29-37.

Yart, L., F. Dessauge, L. Finot, S. Barbey, P.-G. Marnet, and V. Lollivier. 2012. Ovariectomy improves lactation persistency in dairy cows. J. Dairy Sci. 95:3794-3802

Yates, A., W. Akanni, M. R. Amode, D. Barrell, K. Billis, D. Carvalho-Silva, C. Cummins, P. Clapham, S. Fitzgerald, L. Gil, C. G. Girón, L. Gordon, T. Hourlier, S. E. Hunt, S. H. Janacek, N. Johnson, T. Juettemann, S. Keenan, I. Lavidas, F. J. Martin, T. Maurel, W. McLaren, D. N. Murphy, R. Nag, M. Nuhn, A. Parker, M. Patricio, M. Pignatelli, M. Rahtz, H. S. Riat, D. Sheppard, K. Taylor, A. Thormann, A. Vullo, S. P. Wilder, A. Zadissa, E. Birney, J. Harrow, M. Muffato, E. Perry, M. Ruffier, G. Spudich, S. J. Trevanion, F. Cunningham, B. L. Aken, D. R. Zerbino, and P. Flicek. 2016. Ensembl 2016. Nucleic Acids Res. 44:D710-D716. https://doi.org/10.1093/nar/gkv1157. 